\title{
Nutritive value, fermentation characteristics, and in situ disappearance kinetics of ensiled warm-season legumes and bahiagrass
}

\author{
J. L. Foster, ${ }^{\star}$ J. N. Carter,† L. E. Sollenberger,‡ A. R. Blount, † R. O. Myer,† M. K. Maddox,† S. C. Phatak,§ \\ and A. T. Adesogan\# ${ }^{1}$ \\ *Texas AgriLife Research, Department of Soil and Crop Sciences, Texas A\&M University, Beeville 78410 \\ †North Florida Research and Education Center, University of Florida-IFAS, Marianna 32446 \\ ‡Department of Agronomy, Institute of Food and Agricultural Science (IFAS), University of Florida, Gainesville 32608 \\ §Horticulture Department, University of Georgia, Athens 30602 \\ \#Department of Animal Sciences, Institute of Food and Agricultural Science (IFAS), University of Florida, Gainesville 32608
}

\begin{abstract}
This study determined the nutritive value, ensiling characteristics, and in situ disappearance kinetics of bahiagrass (Paspalum notatum Flügge 'Tifton 9'), perennial peanut (Arachis glabrata Benth. 'Florigraze'), annual peanut [Arachis hypogaea (L.) 'FL MDR 98'], cowpea [Vigna unguiculata (L.) Walp. 'Iron clay'], and pigeonpea [Cajanus cajan (L.) Millsp. 'GA-2']. All forages were harvested at maturity stages that optimized dry matter (DM) yield and nutritive value. After harvest, forages were wilted to $45 \% \mathrm{DM}$, and 4 replicate bales of each legume and 8 bales of bahiagrass were wrapped in polyethylene and ensiled for $180 \mathrm{~d}$. After each bale was opened, the forage was thoroughly mixed, and representative subsamples were taken for laboratory analysis and in situ incubation. Wilting and ensiling decreased the rumen-undegradable protein, water-soluble carbohydrate, crude protein $(\mathrm{CP})$, and in vitro true digestibility (IVTD) of bahiagrass, perennial peanut, and cowpea, and increased their neutral detergent fiber (NDF) concentrations. Among haylages, CP concentration was greatest for annual peanut, followed by perennial peanut and cowpea, and least for bahiagrass. In contrast, NDF concentration was greater in bahiagrass than in legumes. Pigeonpea had the greatest NDF concentration among legumes and lowest IVTD of all haylages. All haylages were aerobically stable for at least $84 \mathrm{~h}$, but $\mathrm{pH}$ was lower in perennial peanut and cowpea than in pigeonpea. Ammonia- $\mathrm{N}$ concentrations tended to be greater in legume haylages than in bahiagrass haylage. Butyrate concentration was greater in annual and perennial peanut than in bahiagrass. Total VFA concentration was greater in annual and perennial peanut and cowpea haylages than in bahiagrass haylage. Undegradable DM fractions were greater and
\end{abstract}

Received September 8, 2010.

Accepted December 22, 2010

${ }^{1}$ Corresponding author: adesogan@ufl.edu extent of DM degradation was lower in bahiagrass and pigeonpea than in other haylages but lag time and degradation rates did not differ. Annual and perennial peanut and cowpea haylages were as aerobically stable and had greater CP, IVTD, and extent of degradation than did bahiagrass haylage; therefore, they are promising forages for dairy cow diets in the southeastern United States.

Key words: bahiagrass, silage, tropical legume, forage

\section{INTRODUCTION}

Ideally, silage is produced by rapid anaerobic fermentation of plant sugars with little change in the $\mathrm{CP}$ and fiber concentration of the forage ensiled (Muck, 1988). Cool-season grass forages have greater water-soluble carbohydrate (WSC) concentration than legume forages such that during fermentation, their $\mathrm{pH}$ drops rapidly and proteolysis is limited (Contreras-Govea et al., 2006). In comparison, legumes have greater CP concentration, lower WSC concentration, and greater buffering capacity, which collectively make legumes more susceptible to proteolysis (Contreras-Govea et al., 2006). Nevertheless, alfalfa (Medicago sativa L.) and several clover (Trifolium spp.) species are ensiled and commonly used in ruminant livestock diets because of their relatively high $\mathrm{CP}$ concentrations. However, information about the ensiling characteristics, nutritive value, and in situ degradability of warm-season legume forages is limited. Perennial peanut (Arachis glabrata Benth.) is a warm-season legume that has comparable nutritive value to alfalfa. This legume is widely grown in the southeast United States where alfalfa is not adapted (Newman and Chambliss, 2003; French et al., 2006). Perennial peanut silage replaced $50 \%$ of corn silage in a dairy cow ration containing $50 \%$ of concentrate without affecting milk production (Staples et al., 1997). However, establishment of perennial peanut is often more expensive than other forage crops because a longer duration is required (French et al., 2006). 
Seeded warm-season legumes are easier and cheaper to plant and they can be established faster than perennial peanut. Annual peanut (Arachis hypogaea L.) is a seeded warm-season legume that grows well in the southeastern United States and has been successfully ensiled. Annual peanut silage increased DMI when it replaced $50 \%$ of a $100 \%$ corn silage diet fed to nonlactating heifers (Johnson et al., 1979). Cowpea [Vigna unguiculata (L.) Walp.] is also widely adapted in the southeastern United States. Hopkins (1896) found that cowpea silage was $7 \%$ more digestible than clover silage when fed to sheep, and as digestible as corn silage when fed to cattle, but little is known about the ensiling potential of current cultivars. Pigeonpea [Cajanus cajan (L.) Millsp.] is a relatively new forage in the United States (Rao et al., 2002, 2003), which has shown potential for grazing, or hay or silage production in other countries (Ramos de Otero, 1952). To our knowledge, it has not been grown for silage in the United States. The aim of this study was to determine the nutritive value, fermentation characteristics, aerobic stability, and in situ ruminal disappearance kinetics of bahiagrass (Paspalum notatum Flügge 'Tifton 9'), perennial peanut ('Florigraze'), annual peanut ('FL MDR 98'), cowpea ('Iron clay'), and pigeonpea ('GA-2') haylages. Bahiagrass was also evaluated because it is the main pasture forage in the southeast and no published information on ensiled bahiagrass was found.

\section{MATERIALS AND METHODS}

\section{Forage Production}

Legumes were grown and harvested at the University of Florida-Institute of Food and Agricultural Science North Florida Research and Education Center in Marianna, Florida $\left(31^{\circ} \mathrm{N}\right)$. Soil at the site was Chipola loamy sand (loamy, kaolinitic, thermic, Arenic Kanhapludults) and Orangeburg loamy sand (fine-loamy, kaolinitic, thermic, Typic Kandiudults). Cowpea and pigeonpea were inoculated with Bradyrhizobium spp. (Becker Underwood, Inc., Royal Peat, Ames, IA) and seeded at a rate of $56 \mathrm{~kg} / \mathrm{ha}$. Cowpea was drilled at 15 -cm row spacing on four 0.405 -ha plots, whereas pigeonpea was drilled at $66-\mathrm{cm}$ row spacing on a single 2-ha plot. The legumes were harvested at the recommended maturity stage that maximizes both DM yield and nutritive value. Cowpea was harvested when pods began to turn yellow (NDA, 1997) and pigeonpea at pod setting (Le Houérou, 2006). Established stands of perennial (5-yr-old) and annual peanut (7-yr-old with self reseeding) were harvested as first cuttings. Cowpea, perennial, and annual peanut were cut to a stubble height of $10 \mathrm{~cm}$, whereas pigeonpea was cut to $40-\mathrm{cm}$ stubble height (Le Houérou, 2006). Bahiagrass was from an established stand (7-yr-old) and the field was fertilized with $390 \mathrm{~kg} / \mathrm{ha}$ of $17: 17: 17$ ratio of $\mathrm{N}: \mathrm{P}_{2} \mathrm{O}_{5}: \mathrm{K}_{2} \mathrm{O}$ in late spring. After each cutting, the bahiagrass was top dressed with $280 \mathrm{~kg} /$ ha of fertilizer (30:0:0:0.6 ratio of $\left.\mathrm{N}: \mathrm{P}_{2} \mathrm{O}_{5}: \mathrm{K}_{2} \mathrm{O}: \mathrm{S}\right)$, and the third cutting, taken after 5 -wk regrowth was used in this experiment. Legumes and bahiagrass were harvested using a mower conditioner (New Holland, Haybine model 474, New Holland Agriculture, New Holland, PA). After wilting to $45 \%$ DM (samples were collected from windrows and DM monitored), small (140 kg) round bales were made using a Vermeer 504-L baler (Vermeer Manufacturing Inc., Pella, IA). Bales were wrapped with 6 layers $(50 \%$ overlap) of white polyethylene plastic $(1 \mathrm{~mm})$ using a Kverneland wrapper (model 7510, Kverneland North America, East Syracuse, NY). Eight bales of bahiagrass and 4 bales of each legume were ensiled for at least 180 d.

\section{Laboratory Analyses}

Triplicate samples $(800 \mathrm{~g}$ ) of each forage were taken from representative parts of the respective fields at cutting $(1000 \mathrm{~h})$ for analysis of microbial counts, aerobic stability, chemical composition, fermentation indices, and in situ disappearance kinetics. Samples were immediately weighed and dried $\left(60^{\circ} \mathrm{C}\right)$ to constant weight. Haylage samples were obtained by opening the bales, thoroughly mixing the contents by hand, and representative subsamples were taken for analysis of microbial counts and aerobic stability. Additional representative samples of the bales for determination of chemical composition, fermentation indices, and in situ disappearance kinetics were immediately frozen $\left(-20^{\circ} \mathrm{C}\right)$ until analysis.

Haylage extract $\mathrm{pH}$ was determined by mixing $20 \mathrm{~g}$ of thawed (at $4^{\circ} \mathrm{C}$ for $12 \mathrm{~h}$ ), wet haylage in a blender with $200 \mathrm{~mL}$ of distilled water for $30 \mathrm{~s}$ at high speed. The mixture was filtered through 2 layers of cheesecloth and the $\mathrm{pH}$ was immediately measured using a $\mathrm{pH}$ meter (Accumet, model HP-71, Fisher Scientific, Pittsburg, $\mathrm{PA})$. The filtrate was centrifuged at $1,369 \times g$ for 20 min at $4^{\circ} \mathrm{C}$ and the supernatant was stored $\left(-20^{\circ} \mathrm{C}\right)$ until further analysis of VFA and $\mathrm{NH}_{3}-\mathrm{N}$.

Haylage samples reserved for microbial analysis were heat-sealed within gas-impermeable bags (Kapak/ Scotch Pak, Kapak Corp., Minneapolis, MN), placed in an insulated cooler and transported on the same day to the American Bacteriological and Chemical Research Corporation in Gainesville, Florida. Yeasts and molds were enumerated by pour plating in Standard Methods (M124) agar, to which 4\% chloramphenicol and chlortetracycline were added (Tournas et al., 1998). 
Aerobic stability was measured by placing thermocouple wires at the center of a polyethylene bag containing $800 \mathrm{~g}$ of haylage within an open-top polystyrene box covered with 2 layers of cheesecloth to prevent drying. The thermocouple wires were connected to data loggers (Campbell Scientific, Inc., North Logan, UT) that recorded the temperature every $30 \mathrm{~min}$ for $21 \mathrm{~d}$. Aerobic stability was denoted by the time that elapsed before a $2^{\circ} \mathrm{C}$ rise in silage temperature above ambient temperature $\left(18\right.$ to $25^{\circ} \mathrm{C}$ ).

Samples of forage taken before and after ensiling were weighed and dried at $60^{\circ} \mathrm{C}$ for $48 \mathrm{~h}$ for $\mathrm{DM}$ determination. Dried samples were ground to pass through a 1-mm screen in a Wiley mill (Arthur H. Thomas Company, Philadelphia, PA). All samples were analyzed for ash by combustion in a muffle furnace at $600^{\circ} \mathrm{C}$ for 8 h. Total $\mathrm{N}$ content was determined by rapid combustion using a macro elemental $\mathrm{N}$ analyzer (Elementar, vario MAX CN, Elementar Americas, Mount Laurel, $\mathrm{NJ})$ and used to compute $\mathrm{CP}(\mathrm{CP}=\mathrm{N} \times 6.25)$. Concentrations of NDF and ADF were measured using the method of Van Soest et al. (1991) in an Ankom 200 Fiber Analyzer (Ankom Technologies, Macedon, NY). Amylase was used in the analysis and the results were expressed inclusive of residual ash. The $\mathrm{N}$ in ADF residues was measured using methods described previously and ADIN reported. Water-soluble carbohydrates were analyzed in haylages with the anthrone reaction assay (Ministry of Agriculture, Fisheries, and Food, 1986). The Van Soest et al. (1966) method and an Ankom Daisy ${ }^{\mathrm{II}}$ Incubator (Ankom Technology) were used to determine in vitro true DM digestibility (IVTD). An adaptation of the Noel and Hambleton (1976) procedure that involved colorimetric quantification of $\mathrm{N}$ was used to determine $\mathrm{NH}_{3}$ - $\mathrm{N}$ with an ALPKEM autoanalyzer (ALPKEM Corporation, Clackamas, OR). Volatile fatty acids were measured using the method of Canale et al. (1984) and a high-performance liquid chromatograph (FL 7485, Hitachi, Tokyo, Japan) coupled to a UV detector (Spectroflow 757, ABI Analytical Kratos Division, Ramsey, NJ) set at $210 \mathrm{~nm}$. The column was a Bio-Rad Aminex HPX-87H (Bio-Rad Laboratories, Hercules, CA) with $0.015 M \mathrm{H}_{2} \mathrm{SO}_{4}$ mobile phase and a flow rate of $0.7 \mathrm{~mL}$ at $45^{\circ} \mathrm{C}$.

\section{In Situ Incubation Procedures}

Pre-ensiling and haylage samples were dried $\left(60^{\circ} \mathrm{C}\right.$ for $48 \mathrm{~h}$ ) in a forced-air oven, ground to pass through a 4-mm screen in the Wiley mill (Arthur H. Thomas Company). Approximately $4.5 \mathrm{~g}$ of sample as fed was weighed into $10 \times 20$-cm polyester bags $(53 \pm 10 \mu \mathrm{m}$ pore size; Bar Diamond, Inc., Parma, ID) in triplicate. Bags were heat-sealed and incubated in the ventral rumen of each of 3 mature Brangus steers $(900 \pm 25$ $\mathrm{kg}$ ) and removed after $0,4,8,16,24,48$, and $96 \mathrm{~h}$. Steers were housed in a pen $(10 \times 20 \mathrm{~m})$ in a covered barn and had ad libitum access to both bahiagrass and perennial peanut hays separately, and water. Use of the animals was approved by the University of Florida Institutional Animal Care and Use Committee. After incubation, bags were rinsed in water to remove rumen contents on the exterior and frozen until all bags had been removed. All bags were then washed together in a cool-rinse cycle in a top-loading washing machine (Kenmore Series 70, Sears, Roebuck and Co., Hoffman Estates, IL) and dried at $55^{\circ} \mathrm{C}$ to constant weight in a forced-air oven. Dried residues were analyzed for NDF and NDIN. The NDIN was determined by measuring the $\mathrm{N}$ in NDF residues and RUP was calculated from NDIN according to Haugen et al. (2006). In situ rumen DM and NDF degradation data were fitted to the first order exponential model with discrete lag (Mertens, 1977) using the iterative Marquardt method and the NLIN procedure of SAS (SAS Institute, Cary, NC). The model is of the form

$$
R_{(t)}=B \times\left(e^{-k_{d}(t-L)}\right)+C,
$$

where $R_{(\mathrm{t})}=$ total indigested residue at any time $t, B=$ insoluble potentially digestible fraction, $k_{d}=$ fractional rate of digestion of $B, t=$ time incubated in the rumen in h, $L=$ discrete lag time in $\mathrm{h}$, and $C=$ fraction not digested after $96 \mathrm{~h}$ of incubation. The wash fraction $A$ was the percentage of substrate washed out of the bag at $0 \mathrm{~h}$. Effective ruminal degradability (extent of digestion, ERD) was calculated using the model of Ørskov and McDonald (1979):

$$
\mathrm{ERD}=A+\left\{B \times\left[k_{d} /\left(k_{d}+k_{p}\right)\right]\right\},
$$

where $k_{p}=$ assumed ruminal passage rate of 0.05 .

\section{Statistical Analyses}

The data were analyzed as a completely randomized design with the MIXED procedure of SAS (SAS Inst. Inc.) and the model included the effect of forage species. Fisher's F-protected Least Significant Difference test was used to separate means when the overall model was significant. Tendencies were declared at $P>0.05$ and $\leq 0.10$.

\section{RESULTS}

\section{Chemical Composition of Pre-Ensiled Forages}

Among pre-ensiled forages, DM concentration was greatest $(P<0.01)$ in annual peanut, followed by pi- 
Table 1. Chemical composition and in vitro true DM digestibility of dried pre-ensiled bahiagrass and four legume forages at harvest

\begin{tabular}{lcccccc}
\hline Item & Bahiagrass & $\begin{array}{c}\text { Annual } \\
\text { peanut }\end{array}$ & $\begin{array}{c}\text { Perennial } \\
\text { peanut }\end{array}$ & Cowpea & Pigeonpea & SEM \\
\hline DM, \% & $26.7^{\mathrm{c}}$ & $37.2^{\mathrm{a}}$ & $24.6^{\mathrm{c}}$ & $16.4^{\mathrm{d}}$ & $29.6^{\mathrm{b}}$ & 0.83 \\
OM, \% of DM & $94.2^{\mathrm{b}}$ & $91.4^{\mathrm{d}}$ & $90.9^{\mathrm{d}}$ & $92.4^{\mathrm{c}}$ & $95.3^{\mathrm{a}}$ & 0.36 \\
CP, \% of DM & $10.9^{\mathrm{c}}$ & $18.9^{\mathrm{a}}$ & $18.5^{\mathrm{a}}$ & $16.6^{\mathrm{ab}}$ & $13.9^{\mathrm{b}}$ & 0.89 \\
NDF, \% of DM & $68.0^{\mathrm{a}}$ & $40.0^{\mathrm{c}}$ & $38.3^{\mathrm{c}}$ & $39.6^{\mathrm{c}}$ & $59.3^{\mathrm{b}}$ & 1.78 \\
WSC, $\%$ of DM & $4.58^{\mathrm{b}}$ & $9.56^{\mathrm{a}}$ & $5.49^{\mathrm{b}}$ & $4.23^{\mathrm{b}}$ & $4.26^{\mathrm{b}}$ & 0.73 \\
ADF, \% of DM & $33.6^{\mathrm{b}}$ & $28.1^{\mathrm{c}}$ & $28.6^{\mathrm{c}}$ & $26.7^{\mathrm{c}}$ & $41.7^{\mathrm{a}}$ & 1.34 \\
ADIN, \% of N & $16.13^{\mathrm{a}}$ & $7.42^{\mathrm{c}}$ & $7.78^{\mathrm{c}}$ & $9.08^{\mathrm{bc}}$ & $13.05^{\mathrm{b}}$ & 1.73 \\
RUP, \% of DM & $3.27^{\mathrm{a}}$ & $2.60^{\mathrm{bc}}$ & $2.67^{\mathrm{b}}$ & $2.15^{\mathrm{c}}$ & $1.38^{\mathrm{d}}$ & 0.16 \\
IVTD, $\%$ & $59.7^{\mathrm{b}}$ & $80.5^{\mathrm{a}}$ & $79.3^{\mathrm{a}}$ & $80.6^{\mathrm{a}}$ & $55.4^{\mathrm{b}}$ & 4.98 \\
\hline
\end{tabular}

${ }^{\mathrm{a}-\mathrm{d}}$ Within a row, means without a common superscript letter differ $(P<0.05)$.

${ }^{1}$ Water-soluble carbohydrates.

${ }^{2}$ In vitro true digestibility.

geonpea, and lowest $(P<0.01)$ in cowpea (Table 1$)$. Organic matter concentration was greatest $(P<0.02)$ in pigeonpea, followed by bahiagrass, and annual and perennial peanut had the lowest values. Crude protein concentration was greater $(P<0.03)$ in legumes than bahiagrass. In contrast, NDF concentration was greater $(P<0.03)$ in bahiagrass than in legumes. Among legumes, $\mathrm{CP}$ concentrations of annual and perennial peanut were greater $(P<0.03)$ than that in pigeonpea, which had the greatest $(P<0.01)$ NDF concentration. Concentration of WSC was greater $(P<0.01)$ in annual peanut than in the other forages. The ADF concentration of pigeonpea was greatest $(P<0.01)$, followed by bahiagrass; however, the ADIN concentration of bahiagrass was greatest $(P<0.02)$ followed by that of pigeonpea. Bahiagrass had the greatest $(P<$ 0.01) RUP concentration, and the RUP concentrations of annual and perennial peanut were greater $(P<0.01)$ than that of pigeonpea, which was least. Annual and perennial peanut and cowpea had greater $(P<0.01)$ IVTD than pigeonpea and bahiagrass.

\section{Chemical Composition of Haylages}

The DM and OM concentrations were not different among haylages (Table 2). Legumes contained greater $(P<0.01) \mathrm{CP}$ concentrations than did bahiagrass, and among legumes, $\mathrm{CP}$ concentration was greatest $(P<$ $0.01)$ in annual peanut and lowest in pigeonpea. Bahiagrass had the greatest $(P<0.02)$ NDF concentration, and among the legume haylages pigeonpea had the greatest $(P<0.01)$ NDF concentration. Pigeonpea had the greatest $(P<0.01)$ ADF concentration, and bahiagrass had similar ADF to annual peanut and cowpea. Perennial peanut and cowpea haylages had greater $(P<0.01)$ RUP concentrations than did bahiagrass or annual peanut haylages. Annual and perennial peanut and cowpea had the greatest $(P<0.01)$ IVTD, whereas pigeonpea had the lowest value.

\section{Fermentation Indices, Microbial Counts, and Aerobic Stability}

The $\mathrm{pH}$ of all haylages exceeded 4.5, and $\mathrm{pH}$ was lower $(P<0.01)$ in perennial peanut and cowpea than in pigeonpea, and lowest in bahiagrass (Table 3 ). Ammonia- $\mathrm{N}$ concentrations tended to be greater $(P<$ $0.06)$ in legumes than in bahiagrass. No isovalerate, valerate, or isobutyrate was detected. Concentrations of VFA and lactate were generally low and lactate concentration was greater $(P<0.03)$ in annual peanut haylage than that in all other haylages except cowpea. Acetate concentration was greater $(P<0.05)$ in annual peanut and cowpea haylages than in perennial peanut or bahiagrass haylages. Butyrate concentration was greater $(P<0.01)$ in annual and perennial peanut than in bahiagrass. Total VFA concentration was greater in annual and perennial peanut and cowpea haylages than in bahiagrass haylage. The lactate:acetate ratio tended $(P=0.10)$ to be lower in pigeonpea haylages than in annual and perennial peanut haylages. Yeast and mold counts and aerobic stability were not different $(P>$ $0.10)$ among haylages and all haylages were aerobically stable for at least $84 \mathrm{~h}$ (Table 4).

\section{Disappearance Kinetics}

Among pre-ensiled forages, the wash DM fraction was greater $(P<0.01)$ for legumes than for bahiagrass, and was greatest $(P<0.01)$ for cowpea followed by annual peanut and least for pigeonpea (Table 5). The potentially degradable DM fraction was greatest $(P<$ 0.01 ) for bahiagrass, and it was greater for annual and perennial peanut and cowpea than for pigeonpea. The 
Table 2. Chemical composition and in vitro true DM digestibility of bahiagrass haylage and warm-season legume haylages

\begin{tabular}{lcccccc}
\hline Item & Bahiagrass & $\begin{array}{c}\text { Annual } \\
\text { peanut }\end{array}$ & $\begin{array}{c}\text { Perennial } \\
\text { peanut }\end{array}$ & Cowpea & Pigeonpea & SEM \\
\hline DM, \% & 51.7 & 55.7 & 49.7 & 52.9 & 46.9 & 2.32 \\
OM, \% of DM & 93.5 & 93.2 & 92.6 & 92.6 & 95.0 & 1.21 \\
CP, \% of DM & $8.79^{\mathrm{d}}$ & $18.9^{\mathrm{a}}$ & $15.8^{\mathrm{b}}$ & $15.5^{\mathrm{b}}$ & $13.2^{\mathrm{c}}$ & 0.79 \\
NDF, \% of DM & $70.9^{\mathrm{a}}$ & $42.8^{\mathrm{c}}$ & $40.8^{\mathrm{c}}$ & $45.5^{\mathrm{c}}$ & $65.2^{\mathrm{b}}$ & 2.33 \\
WSC, \% of DM & $3.72^{\mathrm{ab}}$ & $5.82^{\mathrm{a}}$ & $3.04^{\mathrm{b}}$ & $3.88^{\mathrm{ab}}$ & $2.4^{\mathrm{c}}$ & 0.89 \\
ADF, \% of DM & $36.5^{\mathrm{b}}$ & $37.1^{\mathrm{b}}$ & $29.9^{\mathrm{c}}$ & $35.2^{\mathrm{bc}}$ & $48.9^{\mathrm{a}}$ & 2.27 \\
ADIN, \% of N & $13.93^{\mathrm{b}}$ & $7.68^{\mathrm{c}}$ & $7.98^{\mathrm{c}}$ & $8.11^{\mathrm{c}}$ & $22.14^{\mathrm{a}}$ & 1.49 \\
RUP, \% of DM & $1.01^{\mathrm{c}}$ & $0.82^{\mathrm{c}}$ & $2.18^{\mathrm{a}}$ & $1.84^{\mathrm{ab}}$ & $1.72^{\mathrm{b}}$ & 0.12 \\
IVTD, $\%$ & $58.6^{\mathrm{b}}$ & $74.1^{\mathrm{a}}$ & $74.5^{\mathrm{a}}$ & $71.3^{\mathrm{a}}$ & $45.4^{\mathrm{c}}$ & 3.94 \\
\hline
\end{tabular}

${ }^{\mathrm{a}-\mathrm{d}}$ Within a row, means without a common superscript letter $\operatorname{differ}(P<0.05)$.

${ }^{1}$ Water-soluble carbohydrates.

${ }^{2}$ In vitro true digestibility.

undegradable DM fraction was greatest $(P<0.01)$ for pigeonpea and did not differ among the other forages. The ERD was greater $(P<0.01)$ for annual and perennial peanut and cowpea than for bahiagrass or pigeonpea. The lag time was longer $(P<0.01)$ for bahiagrass than for the legumes, and the rate of degradation was slower $(P<0.01)$ for bahiagrass than for all legumes, except pigeonpea. Among legumes, the lag time and rate of degradation were not different $(P>0.14)$.

Among haylages, the wash DM fraction was greatest $(P<0.01)$ for annual peanut, followed by cowpea, and least for bahiagrass. Bahiagrass haylage contained the greatest $(P<0.01)$ potentially degradable DM fraction, followed by perennial peanut, cowpea, annual peanut, and pigeonpea, in that order. The undegradable DM fraction was greatest $(P<0.01)$ for pigeonpea haylage, followed by bahiagrass, and least for perennial peanut. The ERD was lower $(P<0.01)$ for bahiagrass and pigeonpea haylages than for the other legumes. Lag time and rate of disappearance of DM were not different $(P$ $>0.49$ ) among haylages.

Among pre-ensiled forages, the wash NDF fraction was greatest $(P<0.01)$ for annual peanut but did not differ among the other forages (Table 6 ). The potentially degradable NDF fraction and ERD were greatest $(P$ $<0.01$ ) for bahiagrass, least for pigeonpea, but did not differ among the remaining forages. The undegraded NDF was greatest $(P<0.01)$ for pigeonpea and least $(P<0.01)$ for bahiagrass. The lag time before NDF degradation and rate of NDF disappearance were not different $(P>0.40)$ among the forages.

The wash NDF fraction was greatest $(P<0.01)$ for annual peanut and cowpea haylages and least for bahiagrass haylage. Bahiagrass haylage had the greatest $(P<0.01)$ potentially degradable NDF fraction, followed by perennial peanut and cowpea, and pigeonpea had the least. Pigeonpea had the greatest $(P<0.01)$ undegradable NDF fraction, whereas bahiagrass had the least $(P<0.05)$ undegradable NDF fraction. The ERD was greatest $(P<0.01)$ for perennial peanut and least for bahiagrass and pigeonpea haylages. The lag time before onset of NDF degradation was not different $(P>0.58)$ among haylages; however, the rate of NDF disappearance was fastest $(P<0.03)$ for perennial peanut haylage, intermediate for annual peanut haylage, and slower for bahiagrass, pigeonpea, and cowpea haylages.

\section{DISCUSSION}

\section{Chemical Composition}

Published information on the nutritive value of bahiagrass silage was not found. Bermudagrass [Cynodon

Table 3. Fermentation characteristics of bahiagrass haylage and warm-season legume haylages

\begin{tabular}{lcccccc}
\hline Item & Bahiagrass & $\begin{array}{c}\text { Annual } \\
\text { peanut }\end{array}$ & $\begin{array}{c}\text { Perennial } \\
\text { peanut }\end{array}$ & Cowpea & Pigeonpea & SEM \\
\hline $\mathrm{pH}$ & $5.11^{\mathrm{b}}$ & $5.18^{\mathrm{ab}}$ & $4.60^{\mathrm{c}}$ & $4.82^{\mathrm{bc}}$ & $5.43^{\mathrm{a}}$ & 0.14 \\
$\mathrm{NH}_{3} \mathrm{~N}, \%$ of total N & 11.6 & 23.3 & 17.6 & 23.0 & 18.2 & 3.30 \\
Lactate, \% of DM & $0.95^{\mathrm{b}}$ & $3.85^{\mathrm{a}}$ & $2.14^{\mathrm{b}}$ & $2.66^{\mathrm{ab}}$ & $1.04^{\mathrm{b}}$ & 0.73 \\
Acetate, \% of DM & $0.57^{\mathrm{c}}$ & $1.65^{\mathrm{a}}$ & $0.89^{\mathrm{bc}}$ & $2.26^{\mathrm{a}}$ & $1.46^{\mathrm{ab}}$ & 0.35 \\
Propionate, \% of DM & 0.06 & 0.08 & 0.00 & 0.10 & 0.00 & 0.07 \\
n-Butyrate, \% of DM & $0.39^{\mathrm{b}}$ & $1.19^{\mathrm{a}}$ & $1.05^{\mathrm{a}}$ & $0.74^{\mathrm{ab}}$ & $0.39^{\mathrm{ab}}$ & 0.35 \\
Total VFA, \% of DM & $0.68^{\mathrm{b}}$ & $2.88^{\mathrm{a}}$ & $1.90^{\mathrm{a}}$ & $3.05^{\mathrm{a}}$ & $1.83^{\mathrm{ab}}$ & 0.57 \\
Lactate:acetate & 1.7 & 2.7 & 2.5 & 1.2 & 0.9 & 0.6 \\
\hline
\end{tabular}

${ }^{\mathrm{a}-\mathrm{c}}$ Within a row, means without a common superscript letter differ $(P<0.05)$. 
Table 4. Microbial counts and aerobic stability of bahiagrass and warm-season legume haylages

\begin{tabular}{lcccccc}
\hline Item & Bahiagrass & $\begin{array}{c}\text { Annual } \\
\text { peanut }\end{array}$ & $\begin{array}{c}\text { Perennial } \\
\text { peanut }\end{array}$ & Cowpea & Pigeonpea & SEM \\
\hline Yeasts, log cfu/g of fresh haylage & 2.9 & 2.8 & 2.6 & 2.4 & 3.0 & 1.0 \\
Molds, log cfu/g of fresh haylage & 2.5 & 3.2 & 2.4 & 3.5 & 3.5 & 0.6 \\
Aerobic stability, h & 280 & 125 & 131 & 187 & 84 & 88 \\
\hline
\end{tabular}

dactylon (L.) Pers.] is a $\mathrm{C}_{4}$ grass adapted to similar environments, and changes in the $\mathrm{CP}$ and NDF concentrations of bahiagrass due to ensiling in this study were similar to those reported for wilted, ensiled Coastcross-1 and Suwanee bermudagrass (Bates et al., 1989). The chemical composition of the haylages approximated published values for bermudagrass haylage (Bates et al., 1989; Ruiz et al., 1995), annual peanut haylage (Johnson et al., 1979), pigeonpea silage (Francia et al., 1993), and perennial peanut haylage (Bates et al., 1989) or silage (Staples et al., 1997). Published information on the nutritive value of cowpea haylage was not found despite the existence of such data for mixed cowpea-grass or cowpea-cereal silages.

The greater CP concentration and IVTD, and lower NDF concentration of pre-ensiled legumes versus bahiagrass is consistent with the literature on the nutritive value of these forages (Meissner and Paulsmeier, 1995). Unlike grasses, legumes have a symbiotic relationship with $\mathrm{N}$-fixing bacteria leading to increased $\mathrm{N}$ in the plant (Leep et al., 2002). The lower IVTD and immediately soluble fraction of the bahiagrass in this study is partly because photosynthetic cells in the leaf tissue of $\mathrm{C}_{4}$ grasses are arranged in Kranz structures and often contain girder structures, which collectively increase their NDF concentration and decrease ruminal microbial degradation, whereas similar anatomical features are lacking in $\mathrm{C}_{3}$ legumes (Wilson, 1994). Low RUP concentrations in all forages indicate that most of the
$\mathrm{N}$ in the forages was rumen degradable. Differences in nutritive value among the legumes are attributable to their physiological and morphological differences. Pigeonpea haylage had lower IVTD because of its large, woody stem (Masama et al., 1997) and greater structural carbohydrate concentration than typical herbaceous forage legumes.

Most forages had lower CP concentrations after ensiling because proteolysis occurs during wilting and ensiling (Petit and Tremblay, 1992) because of plant enzymatic activity and microbial fermentation. That similar losses of CP did not occur in annual peanut haylages suggests that it contained less hydrolyzable protein. Wilting and ensiling increased the NDF concentrations of all forages and, thereby, decreased their IVTD values. This may have been due to leaf losses during wilting as well as losses of CP and WSC due to enzymatic hydrolysis and microbial respiration and fermentation (Waldo et al., 1973; Verbič et al., 1999). Such effects were more pronounced in cowpea and pigeonpea likely because the lower initial DM concentration of cowpea and the thick, woody stems of pigeonpea necessitated longer wilting periods.

\section{Fermentation Indices, Microbial Counts, and Aerobic Stability}

A pH range of 4.6 to 5.2 is expected for legume silages or haylages and a range of 4.4 to 5.0 is expected

Table 5. In situ DM disappearance kinetics of bahiagrass and warm-season legumes at harvest and after ensiling

\begin{tabular}{|c|c|c|c|c|c|c|}
\hline Item & Bahiagrass & $\begin{array}{l}\text { Annual } \\
\text { peanut }\end{array}$ & $\begin{array}{c}\text { Perennial } \\
\text { peanut }\end{array}$ & Cowpea & Pigeonpea & SEM \\
\hline \multicolumn{7}{|l|}{ Pre-ensiled forage } \\
\hline Wash fraction, \% & $18.6^{\mathrm{e}}$ & $37.2^{\mathrm{b}}$ & $31.6^{\mathrm{c}}$ & $40.0^{\mathrm{a}}$ & $22.4^{\mathrm{d}}$ & 0.5 \\
\hline Undegradable fraction, $\%$ & $21.4^{\mathrm{b}}$ & $19.0^{\mathrm{b}}$ & $20.2^{\mathrm{b}}$ & $18.7^{\mathrm{b}}$ & $49.8^{\mathrm{a}}$ & 2.1 \\
\hline Extent of digestion, $\%$ & $42.3^{\mathrm{b}}$ & $65.9^{\mathrm{a}}$ & $63.2^{\mathrm{a}}$ & $68.4^{\mathrm{a}}$ & $38.6^{\mathrm{b}}$ & 2.9 \\
\hline Lag time, $\mathrm{h}$ & $12.58^{\mathrm{a}}$ & $3.51^{\mathrm{b}}$ & $3.56^{\mathrm{b}}$ & $3.35^{\mathrm{b}}$ & $3.16^{\mathrm{b}}$ & 0.63 \\
\hline \multicolumn{7}{|l|}{ Haylage } \\
\hline Potentially degradable fraction, $\%$ & $47.7^{\mathrm{a}}$ & $32.9^{\mathrm{d}}$ & $40.8^{\mathrm{b}}$ & $37.8^{\mathrm{c}}$ & $22.2^{\mathrm{e}}$ & 0.91 \\
\hline Undegradable fraction, $\%$ & $29.7^{\mathrm{b}}$ & $22.3^{\mathrm{c}}$ & $18.4^{\mathrm{d}}$ & $20.5^{\mathrm{cd}}$ & $47.2^{\mathrm{a}}$ & 0.9 \\
\hline Extent of digestion, $\%$ & $46.6^{\mathrm{b}}$ & $68.7^{\mathrm{a}}$ & $70.6^{\mathrm{a}}$ & $65.4^{\mathrm{a}}$ & $45.1^{\mathrm{b}}$ & 3.0 \\
\hline Lag time, $\mathrm{h}$ & 5.22 & 3.39 & 4.83 & 2.64 & 3.03 & 1.39 \\
\hline$K_{d}$, per $\mathrm{h}$ & 0.09 & 0.15 & 0.14 & 0.08 & 0.11 & 0.37 \\
\hline
\end{tabular}

${ }^{\mathrm{a}-\mathrm{e}}$ Within a row, means without a common superscript letter differ $(P<0.05)$.

${ }^{1}$ Fractional rate of digestion. 
Table 6. In situ NDF disappearance (DM basis) kinetics of bahiagrass and 4 warm-season legumes at harvest and after ensiling

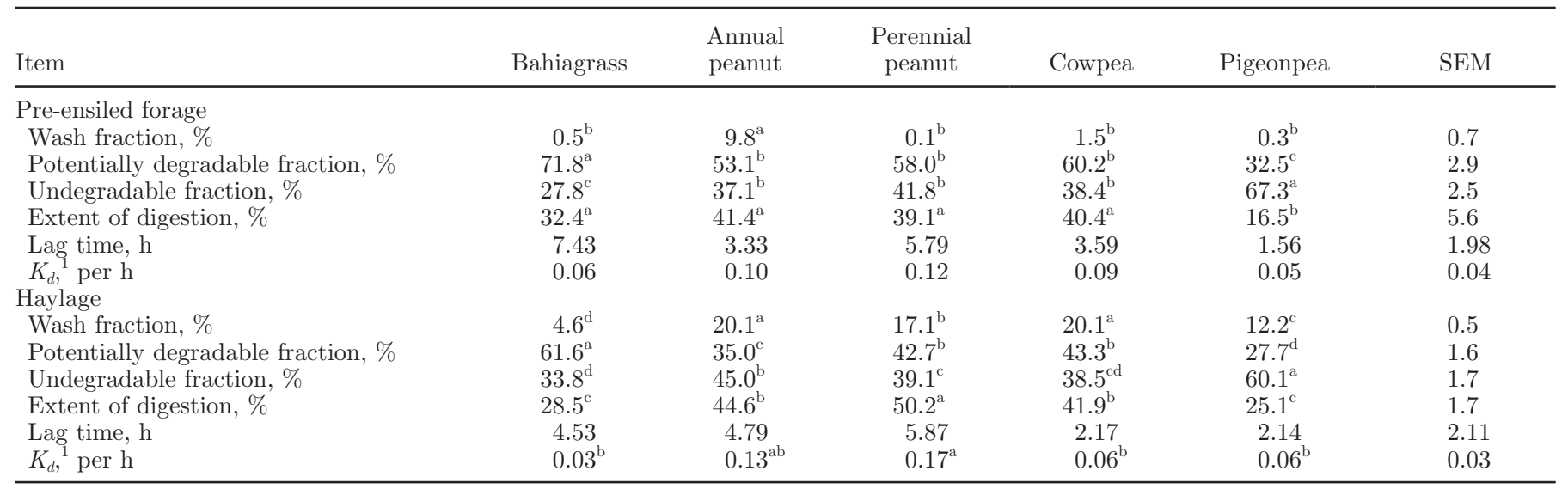

${ }^{\mathrm{a}-\mathrm{d}}$ Within a row, means without a common superscript letter differ $(P<0.05)$.

${ }^{1}$ Fractional rate of digestion.

for grass ensiled when the DM concentration is greater than $350 \mathrm{~g} / \mathrm{kg}$ (McKersie, 1985; Heinrichs and Ishler, 2000). Therefore, bahiagrass and pigeonpea had higher than preferred $\mathrm{pH}$ values, but the other haylages had values within the normal range. Nevertheless, all haylages had $\mathrm{pH}$ values that exceeded the limit (4.0) for decreasing proteolysis and clostridial activity (Muck, 1988). Consequently, all haylages had $\mathrm{NH}_{3}-\mathrm{N}$ concentrations above the threshold of $100 \mathrm{~g}$ of total $\mathrm{N} / \mathrm{kg}$ of DM, which signifies minimal proteolysis (Seglar, 2003). Due to their greater $\mathrm{CP}$ concentrations, all legume haylages had $\mathrm{NH}_{3}-\mathrm{N}$ concentrations above the threshold $(15 \%$ DM of total N) signifying moderate proteolysis (Seglar, 2003). Slightly greater butyrate concentrations in the haylages suggest that the proteolysis was partly caused by clostridial activity (Cai, 1999).

Characteristics of well-preserved silages include a $\mathrm{pH}$ at or below 4.0, a lactate:acetate ratio above 2.0 (Owens et al., 1999), a butyrate concentration below 1\% DM (Cai, 1999), and an $\mathrm{NH}_{3}-\mathrm{N}$ concentration below $10 \%$ DM of total N. Therefore, none of the haylages had an ideal fermentation. The high $\mathrm{pH}$ of the haylages is explained by their low total VFA concentrations, which are likely attributable to their low WSC concentration and high buffering capacity (Umana et al., 1991; Adesogan et al., 2004). The low lactate concentrations and low lactate:acetate ratios indicate the predominance of less efficient heterofermentative pathways during ensiling of the forages (McDonald et al., 1991).

Yeast and mold counts were lower than the threshold (5 log cfu/g) at which such microorganisms decrease aerobic stability (Seglar, 2003); consequently, all of the forages were relatively stable. The low yeast and mold counts and relative stability of these haylages is partly attributable to their high butyrate concentra- tions (Woolford, 1975) and the low WSC concentration of the pre-ensiled forages (Weinberg et al., 1993a, b; McAllister et al., 1998; Adesogan et al., 2004; Dean et al., 2005). Aerobic stability has been demonstrated to exceed $384 \mathrm{~h}$ in alfalfa silage (McAllister et al., 1998) and $96 \mathrm{~h}$ in bermudagrass silage (Adesogan et al., 2004).

\section{Disappearance Kinetics}

Disappearance kinetics among forages is a function of their nutritive value, morphology, and physiology. The DM wash fraction was greater, and thus the potentially degradable fraction lower, for legumes than for bahiagrass because legumes typically have lower structural carbohydrate concentrations (Wilson, 1994). Plant and microbial proteolysis during wilting and deamination during ensiling result in increased solubility of silage (Merchen and Satter, 1983), and these processes were likely more extensive in the legumes due to their greater $\mathrm{CP}$ concentration. Bahiagrass pre-ensiled forage and haylage had greater potentially degradable DM and NDF fractions than did the legumes because legumes typically have more lignin than grasses (Wilson, 1994; Foster et al., 2009a). However, the extent of DM and NDF degradation was greater among perennial and annual peanut and cowpea than for pigeonpea and bahiagrass due to the higher NDF concentrations of the latter 2. Lag time before DM and NDF degradation of the pre-ensiled forage was or tended to be longer for bahiagrass than for legumes due to the greater NDF concentration of bahiagrass and because the reticulate venation of legume leaves allows for more rapid attachment of ruminal microbes and degradation than does the parallel venation of grass leaves (Frame, 2005). The 
latter also explains the trend for greater DM degradation rates of pre-ensiled legumes versus the bahiagrass forage. Such differences may have been less apparent in haylages due to interactions between acidic fermentation products and structural carbohydrates in the forages (Dewar et al., 1963; Nizami et al., 2009).

Among legumes, pigeonpea was the least desirable forage or haylage due to greater undegradable DM and NDF fractions and lower potentially degradable DM and NDF fractions, resulting in the lowest extents of degradation. These factors are partly attributable to the longer, thicker stem and greater NDF and lignin concentrations of pigeonpea (Foster et al., 2009c). The poorer in situ degradability of pigeonpea also explains why supplementation of bahiagrass with annual or perennial peanut or cowpea hays or haylages resulted in greater digestibility and intake by lambs than when supplemented with pigeonpea haylage or hay (Foster et al., 2009a,b).

\section{CONCLUSIONS}

This study demonstrates that ensiling of bahiagrass, annual peanut, perennial peanut, cowpea, and pigeonpea decreased CP and WSC concentrations, which resulted in higher NDF concentrations and decreased IVTD. Haylage $\mathrm{pH}$ and butyrate concentrations were relatively high, whereas lactate and VFA concentrations were low, indicating that additive treatment may be necessary to optimize the fermentation of these forages. Yeast and mold counts were also low in all forages; consequently, haylages were stable for at least $84 \mathrm{~h}$. Except for pigeonpea, legume haylages were more digestible in vitro than bahiagrass haylage, and they had greater $\mathrm{CP}$ concentrations. The high ADIN, undegradable fraction, and low in vitro digestibility of pigeonpea haylage militate against its use in dairy cow diets. However, annual and perennial peanut and cowpea haylages can be potentially important energy and protein sources for dairy cows fed warm-season grasses due to their relatively high in vitro digestibility, $\mathrm{CP}$ concentrations, and aerobic stability. Future studies should evaluate effects of incorporating these legumes in diets of dairy cows on milk production as well as effects of adding bacterial or chemical additives or fermentable carbohydrate sources on their fermentation in silos.

\section{REFERENCES}

Adesogan, A. T., N. Krueger, M. B. Salawu, D. B. Dean, and C. R. Staples. 2004. The influence of treatment with dual purpose bacterial inoculants or soluble carbohydrates on the fermentation and aerobic stability of bermudagrass. J. Dairy Sci. 87:3407-3416.

Bates, D. B., W. E. Kunkle, C. G. Chambliss, and R. P. Cromwell. 1989. Effect of dry matter and additives on bermudagrass and rhizoma peanut round bale silage. J. Prod. Agric. 2:91-96.
Cai, Y. 1999. Identification and characterization of Enterococcus species isolated from forage crops and their influence on silage fermentation. J. Dairy Sci. 82:2466-2471.

Canale, A., M. E. Valente, and A. Ciotti. 1984. Determination of volatile carboxylic acids (C1-C5) and lactic acid in aqueous acid extracts of silage by high-performance liquid chromatography. J. Sci. Food Agric. 35:1178-1182.

Contreras-Govea, F. E., K. A. Albrecht, and R. E. Muck. 2006. Spring yield and silage characteristics of kura clover, winter wheat, and in mixtures. Agron. J. 98:781-787.

Dean, D. B., A. T. Adesogan, N. Krueger, and R. C. Littell. 2005. Effect of fibrolytic enzymes on the fermentation characteristics, aerobic stability, and digestibility of bermudagrass silage. J. Dairy Sci. 88:994-1003.

Dewar, W. A., P. McDonald, and R. Whittenbury. 1963. The hydrolysis of grass hemicelluloses during ensilage. J. Sci. Food Agric. 14:411-417.

Foster, J. L., A. T. Adesogan, J. N. Carter, R. O. Myer, A. R. Blount, and S. C. Phatak. 2009a. Intake, digestibility, and nitrogen retention by sheep supplemented with warm-season legume haylages or soybean meal. J. Anim. Sci. 87:2899-2905.

Foster, J. L., A. T. Adesogan, J. N. Carter, R. O. Myer, A. R. Blount, and S. C. Phatak. 2009b. Intake, digestibility, and nitrogen retention by sheep supplemented with warm-season legume hays or soybean meal. J. Anim. Sci. 87:2891-2898.

Foster, J. L., A. T. Adesogan, J. N. Carter, L. E. Sollenberger, A. R. Blount, R. O. Myer, S. C. Phatak, and M. K. Maddox. 2009c. Annual legumes for forage systems in the United States Gulf Coast region. Agron. J. 101:415-421.

Frame, J. 2005. Forage legumes for temperate grasslands. FAO. United Nations. Science Publishers, Inc., Enfield, NH.

Francia, U., S. Terramoccia, and F. Martillotti. 1993. Productive and nutritive characteristics of the species of Cajanus cajan as forage and grain. REUR Technical Series - FAO Regional Office for Europe. 28:44-46. FAO, Rome, Italy

French, E. C., G. M. Prine, and A. R. Blount. 2006. Perennial peanut: An alternative forage of growing importance. Univ. of FL Agron. Dept., FL Cooperative Extension Service, Inst. Food and Agric. Sci. Publ. No. SS-AGR-39. Accessed Mar. 3, 2007. http://edis.ifas. ufl.edu/AA148.

Haugen, H. L., M. J. Lamothe, T. J. Klopfenstein, D. C. Adams, and M. D. Ullerich. 2006. Estimation of undegradable intake protein in forages using neutral detergent insoluble nitrogen at a single in situ time point. J. Anim. Sci. 84:651-659.

Heinrichs, J., and V. Ishler. 2000. Evaluating forage quality by visual appraisal, $\mathrm{pH}$, and dry matter content. Pennsylvania State Univ. Dept. of Dairy and Anim. Sci. and Cooperative Extension. Accessed Dec. 14, 2007. http://www.das.psu.edu/dairynutrition/ documents/evalfor.pdf.

Hopkins, C. G. 1896. Composition and digestibility of corn ensilage, cow pea ensilage, soja bean ensilage, and corn-fodder. Univ. of Illinois Ag. Exp. Station. Bull. No. 43. Accessed Jan. 17, 2008. http://www.ideals.uiuc.edu/bitstream/2142/3116/1/compositiondiges00hopk.pdf.

Johnson, J. C. Jr., J. L. Butler, and E. J. Williams. 1979. Composition and nutritive value of whole plant peanuts (Arachis hypogaea L.) ensiled with and without propionic acid-formaldehyde treatment. J. Dairy Sci. 62:1258-1263.

Le Houérou, H. N. 2006. Cajanus cajan (L.) Millsp. Available at http://www.fao.org/ag/agP/AGPC/doc/gbase/data/Pf000150. HTM (verified 12 Jan. 2006). FAO, Worldwide.

Leep, R., P. Jeranyama, D.-H. Min, T. Dietz, S. Bughrara, and J. Isleib. 2002. Grazing effects on herbage mass and composition in grass-birdsfoot trefoil mixtures. Agron. J. 94:1257-1262.

Masama, E., J. H. Topps, N. T. Ngongoni, and B. V. Maasdorp. 1997. Effects of supplementation with foliage from the tree legumes Acacia angustissima, Cajanus cajan, Calliandra calothyrsus and Leucaena leucephala on feed intake, digestibility and nitrogen metabolism of sheep given maize stover ad libitum. Anim. Feed Sci. Technol. 69:233-240. 
McAllister, T. A., R. Feniuk, Z. Mir, P. Mir, L. B. Selinger, and K.-J. Cheng. 1998. Inoculants for alfalfa silage: Effects on aerobic stability, digestibility and the growth performance of feedlot steers. Livest. Prod. Sci. 53:171-181.

McDonald, P., N. Henderson, and S. Heron. 1991. The Biochemistry of Silage. 2nd ed. Chalcombe Publications, Marlow, UK.

McKersie, B. D. 1985. Effect of $\mathrm{pH}$ on proteolysis in ensiled legume forage. Agron. J. 77:81-86.

Meissner, H. H., and D. V. Paulsmeier. 1995. Plant compositional constituents affecting between-plant and animal species prediction of forage intake. J. Anim. Sci. 73:2447-2457.

Merchen, N. R., and L. D. Satter. 1983. Digestion of nitrogen by lambs fed alfalfa conserved as baled hay or as low moisture silage. J. Anim. Sci. 56:943-951.

Mertens, D. R. 1977. Dietary fiber components: Relationship to the rate and extent of ruminal digestion. Fed. Proc. 36:187-192.

Ministry of Agriculture, Fisheries, and Food. 1986. The Analysis of Agricultural Materials. Reference Book 427. HMSO, London, UK.

Muck, R. E. 1988. Factors influencing silage quality and their implications for management. J. Dairy Sci. 71:2992-3002.

NDA. 1997. Cultivating cowpeas. Natl. Department of Agric. and North West Agric. Dev. Inst. Natl. Department of Agric., Republic of South Africa.

Newman, Y. C., and C. G. Chambliss. 2003. Tropical (summer) forage legume guide. Univ. of Florida, Agron. Dept., Inst. Food Agric. Sci. Circ. SS-AGR-48. Univ. of Florida, Gainesville.

Nizami, A.-S., N. E. Korres, and J. D. Murphy. 2009. Review of the integrated process for the production of grass biomethane. Environ. Sci. Technol. 43:8496-8508.

Noel, R. J., and L. G. Hambleton. 1976. Collaborative study of a semiautomated method for determination of crude protein in animal feeds. J. Assoc. Off. Anal. Chem. 59:134-140.

Ørskov, E. R., and I. McDonald. 1979. The estimation of protein degradability in the rumen from incubation measurements weighted according to rate of passage. J. Agric. Sci. 92:499-503.

Owens, V. N., K. A. Albrecht, R. E. Muck, and S. H. Duke. 1999. Protein degradation and fermentation characteristics of red clover and alfalfa silage harvested with varying levels of total nonstructural carbohydrates. Crop Sci. 39:1873-1880.

Petit, H. V., and G. F. Tremblay. 1992. In situ degradability of fresh grass and grass conserved under different harvesting methods. J. Dairy Sci. 75:774-781.

Ramos de Otero, J. 1952. Informações sôbre Algumas Plantas Forrageiras. Série Didática Vol. 11. Serviço de Informação Agrícola, Ministério de Agricultura, Rio de Janeiro, Brazil.

Rao, S. C., S. W. Coleman, and H. S. Mayeux. 2002. Forage production and nutritive value of selected pigeonpea ecotypes in the southern Great Plains. Crop Sci. 42:1259-1263.
Rao, S. C., W. A. Phillips, H. S. Mayeux, and S. C. Phatak. 2003. Potential grain and forage production of early maturing pigeonpea in the southern Great Plains. Crop Sci. 43:2212-2217.

Ruiz, T. M., E. Bernal, C. R. Staples, L. E. Sollenberger, and R. N. Gallaher. 1995. Effect of dietary neutral detergent fiber concentration and forage source on performance of lactating cows. J. Dairy Sci. 78:305-319.

Seglar, B. 2003. Fermentation analysis and silage quality testing. Pages 119-136 in Proc. of the Minnesota Dairy Health Conf. Univ. of Minnesota, Minneapolis.

Staples, C. R., S. M. Emanuele, and G. M. Prine. 1997. Intake and nutritive value of Florigraze rhizoma peanut silage for lactating dairy cows. J. Dairy Sci. 80:541-549.

Tournas, V., M. E. Stack, P. B. Mislivec, H. A. Koch, and R. Bandler. 1998. Yeasts, molds and mycotoxins. Pages 18.01-18.11 in Food and Drug Administration Bacteriological Analytical Manual. AOAC Intl., Gaithersburg, MD.

Umana, R., C. R. Staples, D. B. Bates, C. J. Wilcox, and W. C. Mahanna. 1991. Effects of microbial inoculants and(or) sugarcane molasses on the fermentation, aerobic stability, and digestibility of bermudagrass ensiled at two moisture contents. J. Anim. Sci. 69:4588-4601.

Van Soest, P. J., J. B. Robertson, and B. A. Lewis. 1991. Methods for dietary fiber, neutral detergent fiber, and nonstarch polysaccharides in relation to animal nutrition. J. Dairy Sci. 74:3583-3597.

Van Soest, P. J., R. H. Wine, and L. A. Moore. 1966. Estimation of the free digestibility of forages by the in vitro digestion of cell walls. Page 438-441 in Proc. 10th Intl. Grassl. Congr., Helsinki, Finland.

Verbič, J., E. R. Ørskov, J. Žgajnar, X. B. Chen, and V. ŽnidaršičPongrac. 1999. The effect of method of forage preservation on the protein degradability and microbial protein synthesis in the rumen. Anim. Feed Sci. Technol. 82:195-212.

Waldo, D. R., J. E. Keys Jr., and C. H. Gordon. 1973. Preservation efficiency and dairy heifer response from unwilted formic and wilted untreated silages. J. Dairy Sci. 56:129-136.

Weinberg, Z. G., G. Ashbell, A. Azrieli, and I. Brukental. 1993a. Ensiling peas, ryegrass and wheat with additives of lactic acid bacteria (LAB) and cell wall degrading enzymes. Grass Forage Sci. 48:70-78.

Weinberg, Z. G., G. Ashbell, Y. Hen, and A. Azrieli. 1993b. The effect of applying lactic acid bacteria at ensiling on the aerobic stability of silages. J. Appl. Bacteriol. 75:512-518.

Wilson, J. R. 1994. Cell wall characteristics in relation to forage digestion by ruminants. J. Agric. Sci. 122:173-182.

Woolford, M. K. 1975. Microbiological screening of the straight chain fatty acids $\left(\mathrm{C}_{1}-\mathrm{C}_{12}\right)$ as potential silage additives. J. Sci. Food Agric. 26:219-228. 